\title{
Plume-subduction events recorded by KS2 kimberlite indicator minerals from Juína, Brazil
}

\author{
T. JALOWITZKI ${ }^{1}$, F. GERVASONI ${ }^{2}$, H. SUMINO ${ }^{3}$, S. \\ KLEMME $^{4}$, J. BERNDT ${ }^{4}$, M. DALla COSTA ${ }^{1}$, R.A. FUCK ${ }^{1}$ \\ ${ }^{1}$ Universidade de Brasília (UnB) (jalowitzki@unb.br) \\ ${ }^{2}$ Universidade Federal de Goiás (UFG) \\ ${ }^{3}$ University of Tokyo \\ ${ }^{8}$ Universität Münster
}

The Cretaceous Juína Kimberlite Province (JKP, 95-92 Ma) is located in the southwest of the Amazonian Craton, northwest of Mato Grosso, Brazil. Here we present new geochemical and isotopic data of garnet $(n=187)$ and zircon $(n=25)$ megacrysts collected from the KS2 kimberlite. The magmatic zircon megacrysts have $\mathrm{U}-\mathrm{Pb}$ ages of $92.1 \pm 0.7$ Ma. The chondrite-normalized rare earth element (REE) patterns (LREE<HREE), pronounced by $\mathrm{Ce}$ positive anomaly, as well as low trace element contents (e.g. U=7-50 $\mathrm{ppm}, \mathrm{Th}=2-22 \mathrm{ppm}, \Sigma \mathrm{REE}=8-77 \mathrm{ppm}$ ) coupled with positive $\mathrm{Th}, \mathrm{U}, \mathrm{Ta}, \mathrm{Ce}$ and $\mathrm{Hf}$ anomalies are typical of mantle-derived zircon megacrysts in kimberlites. The Ti content (5.3-12.9 $\mathrm{wt} \%$ ) of zircon megacrysts yields a temperature range between 689 and $770{ }^{\circ} \mathrm{C}$, suggesting crystallization at relatively shallow depths in the lithospheric mantle $(<140$ $\mathrm{km}$ ). Garnet xenocrysts are pyrope with \#Mg ranging 63-76, $\mathrm{CaO}$ 3.5-6.6 wt\%, and $\mathrm{Cr}_{2} \mathrm{O}_{3}$ 0.04-4.1 wt\%. They are classified as megacrystic (G1), pyroxenitic (G4), and lherzolitic (G9) garnet. Chondrite-normalized REE concentrations of garnet from different groups have very similar patterns. They show strongly positive-sloped REE pattern with HREE contents between 6.4-15.4 times chondritic and nearly flat to positive slope for MREE and HREE, typical for garnets from fertile (or refertilized) lherzolite xenoliths. The positive correlation between $\mathrm{Y}$ and $\mathrm{Zr}$ reflects high-temperature metasomatism related to a silicate melt with basaltic composition. The ${ }^{3} \mathrm{He} /{ }^{4} \mathrm{He}$ isotope ratios of garnet samples were obtained by crushing extraction method. The results allow to identify the existence of subduction $\left({ }^{3} \mathrm{He} /{ }^{4} \mathrm{He}=1.1-4.0 \quad \mathrm{R}_{\mathrm{A}}\right)$ and plume $\left({ }^{3} \mathrm{He} /{ }^{4} \mathrm{He}=\right.$ 21.4-39.4 $\mathrm{R}_{\mathrm{A}}$ ) mantle sources. The radiogenic helium component might be related to Mesoproterozoic subduction of oceanic crust during the formation of a mobile belt, which was accreted onto the southern edge of the Amazonian Craton between 1.75 and $1.55 \mathrm{Ga}$ in a continental margin setting. The mantle plume component may indicate the Trindade mantle plume track beneath the Brazilian continent at 95-92 Ma. 